\title{
Penggunaan Power Point Game pada Materi Persegi Panjang Kelas VII SMP Muhammadiyah Pagaralam
}

\author{
Okta Wirajaya $^{1}$, Widiawati ${ }^{2}$, Chika Rahayu ${ }^{3}$ \\ ${ }^{1,2,3}$ STKIP Muhammadiyah Pagaralam \\ 1 oktawirajaya@gmail.com
}

\begin{tabular}{l}
\hline \hline Article Info \\
\hline Article history: \\
Received July $29^{\text {th }}, 2019$ \\
Revised Oct $24^{\text {th }}, 2019$ \\
Accepted Nov $15^{\text {th }}, 2019$ \\
\hline
\end{tabular}

Keywords:

Power Point Game;

Rectangular;

Outcomes of Grade

Abstract

The purpose of this study was to find out the learning outcomes of students after the use of Power Point Game on the study of Rectangles in class VII of Pagaralam Muhammadiyah Middle School. The design used in this study is a one shoot case study which is an experiment that is implemented without using a companion group. This study was only conducted in class VII 4, which amounted to 31 people. Based on the data analysis, the results of the post test were obtained with a class average value of 82.8. Thus it can be concluded that the use of Power Point learning media games on rectangular material can improve the learning outcomes of Grade VII students at Muhammadiyah Middle School Pagaralam.

Kata Kunci:

Power Point Game; Persegi Panjang; Hasil Belajar
Abstrak

Tujuan penelitian ini adalah mengetahui hasil belajar siswa setelah digunakannya Power Point Game pada pembelajaran persegi panjang di kelas VII SMP Muhammadiyah Pagaralam. Desain yang digunakan dalam penelitian ini adalah one shoot case study yaitu suatu eksperimen yang pelaksanaannya tanpa menggunakan kelompok pendamping. Penelitian ini hanya dilakukan di kelas VII 4 yang berjumlah 31 orang. Berdasarkan analisis data diperoleh hasil post test dengan nilai rata-rata kelas yaitu 82,8 . Dengan demikian dapat disimpulkan bahwa penggunaan media pembelajaran Power Point Game pada materi persegi panjang dapat meningkatkan hasil belajar siswa kelas VII SMP Muhammadiyah Pagaralam. 
166 | Wirajaya, Widiawati, dan Rahayu: Penggunaan Power Point Game pada Materi Persegi ...

\section{PENDAHULUAN}

Dalam dunia pendidikan, matematika merupakan materi pelajaran yang penting dan tidak dapat ditinggalkan baik pada jenjang sekolah dasar, sekolah menengah, hingga perguruan tinggi. Dalam mempelajari matematika siswa harus mengenal dan memahami objek-objek matematika. Menurut Ruseffendi (2006), objek yang terkait langsung dengan aktifitas belajar matematika meliputi fakta, keterampilan, konsep, dan aturan/prinsip. Keempat objek langsung ini dapat dibedakan antara satu dengan lainnya secara jelas karena masing-masing objek langsung tersebut dapat didefinisi secara jelas. Dari penjelasan tersebut terlihat bahwa di dalam belajar matematika tidak hanya konsep dan prinsip yang dibutuhkan, tetapi juga skill (keterampilan).

Geometri merupakan salah satu bidang kajian dalam materi matematika sekolah, adapun materi geometri SMP yang harus dikuasai siswa sesuai standar isi yang memuat kompetensi dasar meliputi: hubungan antar garis, sudut (melukis sudut dan membagi sudut), segitiga (termasuk melukis segitiga) dan segiempat, teorema Pythagoras, lingkaran (garis singgung sekutu, lingkaran luar dan lingkaran dalam segitiga, dan melukisnya), kubus, balok, prisma, limas, dan jaringjaringnya, kesebangunan dan kongruensi, tabung, kerucut, bola serta menggunakannya dalam pemecahan masalah.

Dalam kurikulum 2013, pembelajaran yang berkaitan dengan ruang lingkup geometri dan pengukuran diberikan pada siswa kelas VII SMP. Salah satu materi untuk ruang lingkup geometri pada semester genap yaitu persegi dan persegi pajang. Menurut Rahayu, C., Putri, R., Zulkardi, \& Hartono2, Y. (2019). ICT On Mathematics Learning Process At Pagaralam Elementary School Teknologi Informasi dan Komunikasi (TIK) di dunia pendidikan sedang dibahas. Permainan edukatif dapat digunakan dalam pembelajaran geometri karena menurut Sumbambi \& Bassey (2013:335) ada beberapa hubungan antara teknik pengajaran yang menggunakan permainan dengan keterampilan siswa dalam memecahkan masalah geometri, dimana siswa yang diajarkan dengan menggunakan permainan mempunyai ketertarikan lebih dalam mempelajari geometri. 
Selain meningkatkan minat siswa, permainan edukatif diharapkan dapat juga meningkatkan hasil belajar siswa. Berdasarkan penelitian sebelumnya yang dilakukan oleh Oktaviani S (2017) dengan judul Penggunaan Power Point Game pada pembelajaran lingkaran di kelas VIII SMP Negeri 1 Tanjung Raja menunjukan bahwa penggunaan permainan edukatif yang diterapkan dalam Power Point Game dapat meningkatkan minat serta hasil belajar siswa. Berdasarkan uraian di atas maka, peneliti tertarik untuk melakukan penelitian dengan judul "Penggunaan Power Point Game Pada Materi Persegi Panjang Terhadap Hasil Belajar Siswa Kelas VII SMP Muhamammadiyah Pagaralam".

Tujuan penelitian ini adalah untuk mengetahui hasil belajar siswa setelah digunakannya Power Point Game pada pembelajaran persegi panjang di kelas VII SMP Muhammadiyah Pagaralam.

\section{METODE PENELITIAN}

Metode yang digunakan dalam penelitian ini adalah metode eksperimen one shoot case study yaitu suatu eksperimen yang pelaksanaanya tanpa menggunakan kelompok pendamping. Peneliti hanya mengadakan treatment satu kali yang diperkirakan sudah mempunyai pengaruh (Arikunto, 2010:124). Penelitian ini dilakukan di SMP Muhammadiyah Pagaralam kelas VII Tahun Pelajaran 2018/2019. Dalam penelitian ini di ambil satu kelas yaitu kelas VII 4 dengan jumlah siswa 31 orang. Adapun teknik dalam pengambilan sampel, penulis akan menggunakan teknik random sampling. Teknik pengumpulan data yang digunakan dalam penelitian ini adalah teknik dokumentasi dan tes.

Dokumentasi digunakan untuk mengumpulkan data, dokumentasi yang digunakan dalam penelitian ini diantaranya silabus, RPP, absensi siswa dan hasil tes siswa, serta foto-foto dan video pada saat proses pembelajaran. Tes digunakan untuk membuktikan apakah penggunaan media Power Point Game pada materi persegi panjang dapat meningkatkan hasil belajar siswa atau tidak. Penelitian kuantitatif, teknik analisis data yang digunakan sudah jelas yaitu diarahkan untuk manjawab rumusan masalah atau menguji hipotesis yang telah dirumuskan dalam 
168 | Wirajaya, Widiawati, dan Rahayu: Penggunaan Power Point Game pada Materi Persegi ...

proposal karena adanya kuantitatif maka teknik analisis data menggunakan metode statistik yang sudah tersedia (Sugiyono, 2013:333).

Mengetahui hasil belajar peserta didik dengan menggunakan Power Point Game yaitu menentukan presentase ketuntasan belajar. Sedangkan presentase ketuntasan belajar dihitung dengan cara membandingkan jumlah peserta didik yang tuntas dengan jumlah peserta didik secara keseluruhan kemudian dikalikan $100 \%$.

\section{HASIL PENELITIAN DAN PEMBAHASAN}

Setelah siswa menggunakan media Power Point Game pada materi persegi panjang, hampir seluruh kelompok siswa mendapatkan nilai yang sempurna. Dengan adanya game pembelajaran yang diadaptasi dari power point siswa dapat berperan aktif dalam menyelesaikan materi persegi panjang, serta daya serap siswa akan lebih maksimal dan pembelajaranpun akan menjadi menyenangkan.

Media pembelajaran Power Point Game merupakan media yang digunakan untuk membantu proses belajar dan pembelajaran sehingga proser belajar mengajar menjadi lebih mudah dipahami serta dapat menarik minat siswa dan hasil yang didapatkan juga maksimal. Dengan siswa berperan aktif dalam menyelesaikan serta mengoperasikan game yang berbasis pembelajaran maka daya serap siswa akan lebih maksimal dan pembelajaranpun akan menjadi menyenangkan. Hasil belajar matematika pada materi persegi panjang dengan menggunakan media Power Point Game dikategorikan baik dengan nilai rata-rata yang didapat siswa pada pertemuan ke-I adalah 89,67, pertemuan ke-II adalah 91,26 dan pertemuan terakhir adalah 81,35 sehingga rata-rata hasil belajarnya diperoleh sebesar 82,8 .

Oleh karena itu, peneliti menyimpulkan bahwa penggunaan media Power Point Game dapat meningkatkan hasil belajar siswa pada materi persegi panjang di kelas VII SMP Muhammadiyah Pagaralam.

\section{SIMPULAN}

Penggunaan media Power Point Game dapat meningkatkan hasil belajar siswa pada materi persegi panjang di kelas VII SMP 
Muhammadiyah Pagaralam. Penggunaan media Power Point Game pada materi persegi panjang dikategorikan baik dengan nilai rata-rata yang didapat siswa pada pertemuan ke-I adalah 89,67, pertemuan ke-II adalah 91,26 dan pertemuan terakhir adalah 81,35 . Hal ini dapat dilihat dari ratarata hasil tes siswa pertemuan ke-I, pertemuan ke-II, dan pertemuan akhir (posttest).

\section{DAFTAR PUSTAKA}

Arikunto, S. (2010). Prosedur Penelitian Suatu Pendekatan Praktik. Jakarta: Rineka Cipta.

Oktaviani, S. (2017). Penggunaan Power Point Game Pada Pembelajaran Lingkaran Di Kelas VIII SMP Negeri 1 Tanjung Raja.

Rahayu, C., Putri, R., Zulkardi, \& Hartono2, Y. (2019). ICT On Mathematics Learning Process At Pagaralam Elementary School. Journal of Physics, 1188.

Ruseffendi. (2006). Pengantar Kepada Membantu Guru Mengembangkan Kompetensinya dalam Pengajaran Matematika untuk Meningkatkan CBSA. Bandung: Tarsito.

Sugiyono. (2012). Metode Penelitian Kuantitatif Kualitatif dan $R \& B$. Bandung: Alfabeta. 
170 | Wirajaya, Widiawati, dan Rahayu: Penggunaan Power Point Game pada Materi Persegi ... 